\title{
Antibiotic Resistance of Salmonella spp. Isolated from Shrimp Farming Freshwater Environment in Northeast Region of Brazil
}

\author{
Fátima C. T. Carvalho, ${ }^{1}$ Oscarina V. Sousa, ${ }^{1}$ Edirsana M. R. Carvalho, ${ }^{1}$ \\ Ernesto Hofer, ${ }^{2}$ and Regine H. S. F. Vieira ${ }^{1}$ \\ ${ }^{1}$ Laboratório de Microbiologia Ambiental e do Pescado, Instituto de Ciências do Mar (LABOMAR), Universidade Federal do Ceará, \\ Avenida Abolicão 3207, CEP 60165-081, Fortaleza, CE, Brazil \\ ${ }^{2}$ Laboratório de Zoonoses Bacterianas, Instituto Oswaldo Cruz (FIOCRUZ)-Pavilhão Rocha Lima, Avenida Brasil 4365, \\ CEP 21040-360, Manguinhos-Rio de Janeiro, RJ, Brazil
}

Correspondence should be addressed to Fátima C. T. Carvalho; fctcarvalho@yahoo.com.br

Received 6 September 2013; Accepted 24 October 2013

Academic Editor: Timothy J. Johnson

Copyright (C) 2013 Fátima C. T. Carvalho et al. This is an open access article distributed under the Creative Commons Attribution License, which permits unrestricted use, distribution, and reproduction in any medium, provided the original work is properly cited.

This study investigated the presence and antibiotic resistance of Salmonella spp. in a shrimp farming environment in Northeast Region of Brazil. Samples of water and sediments from two farms rearing freshwater-acclimated Litopenaeus vannamei were examined for the presence of Salmonella. Afterwards, Salmonella isolates were serotyped, the antimicrobial resistance was determined by a disk diffusion method, and the plasmid curing was performed for resistant isolates. A total of 30 (16.12\%) of the 186 isolates were confirmed to be Salmonella spp., belonging to five serovars: S. serovar Saintpaul, S. serovar Infantis, S. serovar Panama, S. serovar Madelia, and S. serovar Braenderup, along with 2 subspecies: S. enterica serovar houtenae and S. enterica serovar enterica. About twenty-three percent of the isolates were resistant to at least one antibiotic, and twenty percent were resistant to at least two antibiotics. Three strains isolated from water samples (pond and inlet canal) exhibited multiresistance to ampicillin, tetracycline, oxytetracycline, and nitrofurantoin. One of them had a plasmid with genes conferring resistance to nitrofurantoin and ampicillin. The incidence of bacteria pathogenic to humans in a shrimp farming environment, as well as their drug-resistance pattern revealed in this study, emphasizes the need for a more rigorous attention to this area.

\section{Introduction}

The growing demand for shrimp on the international market has boosted inland shrimp farming over the past decades. Marine shrimp culture located miles away from the ocean is a new and fast growing sector of aquaculture [1]. However, shrimp farmed in both salt water and freshwater are becoming increasingly vulnerable to bacterial infection due to the ease with which pathogens are transmitted in aquaculture [2]. As a result, many farmers have made improper use of antibiotics to prevent or treat infections, leading to the dissemination of antimicrobial-resistant strains in aquatic environments [3]. The increase in the incidence of antimicrobialresistant strains is also associated with the presence of plasmids containing resistance genes, providing microbiological populations with a greater genetic flexibility and allowing them to adapt and survive in hostile environments [4]. The addition of antibiotics to shrimp fodder for prophylaxis, treatment of infections, or growth stimulation has contributed to the perpetuation of resistant and pathogenic strains as well [5].

Shrimp farm workers are not only regularly exposed to antibiotics as these are mixed with the fodder, but they are also vulnerable to contamination by multiresistant invasive bacteria, such as Salmonella spp. Patients with Salmonella infection should be treated with antibiotics that are effective against these bacteria $[6,7]$.

The objectives of this study were to investigate the presence of Salmonella strains in shrimp farm environmental samples and to determine the antimicrobial resistance 
profiles among isolated strains from ponds and inlet canals of shrimp farms in Northeast Region of Brazil.

\section{Materials and Methods}

2.1. Sampling. Samples were collected at two farms (A and B) rearing freshwater-acclimated Litopenaeus vannamei located in the estuary of the Jaguaribe River (Jaguaruana City, State of Cear, Brazil). A total of hundred and twenty samples were collected from shrimp farms in two time periods: from June to December 2007 and from June to September 2008. The number of samples was the same in both periods, consisting of water (30) and sediment (30), from ponds and inlet canals.

Sampling covered the complete crop cycle. Water $(2 \mathrm{~L})$ was collected in sterile amber vials and filtered in loco through a many-fold layer (five) of sterile gauze. Gauze was then immersed in $225 \mathrm{~mL}$ lactose broth and incubated for 24 hours at $35^{\circ} \mathrm{C}$.

Each sediment sample consisted of four subsamples from random locations inside the pond or inlet canal pooled into a single homogeneous sample. A $25 \mathrm{~g}$ aliquot was inoculated in $225 \mathrm{~mL}$ lactose broth and incubated for 24 hours at $35^{\circ} \mathrm{C}$.

2.2. Microbiological Analysis. Samples were processed for the presence of Salmonella by using the 3-step technique described by Wallace and Hammack [8]: enrichment with Rappaport-Vassiliadis broth and Tetrathionate broth; plating onto selective media; Hektoen enteric agar; and MacConkey agar (all Difco). Suspicious Salmonella colonies were selected from the plating media and transferred to trypticase soy agar (TSA), triple sugar iron (TSI) agar, lysine iron agar (LIA), and sulfide indole motility (SIM) agar (all Difco). Isolates with typical reactions were biotyped for identification of Salmonella species and subspecies according to Le Minor and Popoff [9], and they were serotyped (serogroups and serovars) using $\mathrm{O}$ and $\mathrm{H}$ antisera agglutination tests, Oswaldo Cruz Institute, RJ, Brazil [9].

2.3. Antimicrobial Susceptibility Testing. The antimicrobial susceptibility was performed by disk diffusion method [10] using commercially available antibiotic-containing disks (LABORCLIN, Brazil): ampicillin (AMP; $10 \mu \mathrm{g}$ ), tetracycline (TET; $30 \mu \mathrm{g})$, gentamicin (GEN; $10 \mu \mathrm{g}$ ), chloramphenicol $(\mathrm{CHO} ; 30 \mu \mathrm{g})$, florfenicol (FLF; $30 \mu \mathrm{g}$ ), ciprofloxacin (CIP; $5 \mu \mathrm{g}$ ), nitrofurantoin (NIT; $300 \mu \mathrm{g}$ ), and nalidixic acid (NAL; $30 \mu \mathrm{g}$ ). The oxytetracycline disks (OTC; $30 \mu \mathrm{g}$ ) were prepared using blank disks ( $6 \mathrm{~mm}$, LABORCLIN) impregnated with the antibiotic solution [11]. These antibiotics were tested according to their use in medicine, veterinary medicine, and farming for the prevention and treatment of diseases in Brazil. For control of test, the following reference strains were used: Salmonella ser. Choleraesuis ATCC10708, Escherichia coli ATCC25922, Pseudomonas aeruginosa ATCC27853, and Staphylococcus aureus ATCC25293.

The breakpoints considered for florfenicol and oxytetracycline, two antibiotics commonly used in shrimp farming to prevent and treat infectious disease outbreaks, were the same for chloramphenicol and tetracycline disks, respectively, according to CLSI [11].

2.4. Plasmid Curing. Strains resistant to more than one antibiotic were submitted to plasmid curing as described by Molina-Aja et al. [12], using Luria-Bertani broth (Difco) supplemented with $0.85 \% \mathrm{NaCl}$ and $100 \mu \mathrm{g} / \mathrm{mL}$ of acridine orange dye. Susceptibility was tested against antibiotics after the process.

2.5. Determination of the Inhibitory and Bactericidal Concentrations. Minimum inhibitory concentration (MIC) and minimum bactericidal concentration (MBC) were determined in strains resistant to antimicrobial test disk diffusion (Kirby-Bauer) according to the broth dilution (macrodilution) technique using Mueller-Hinton broth, Difco CLSI [11].

\section{Results}

Salmonella spp. accounted for 30 (16.12\%) of the 186 suspected strains. Five serovars were identified: $S$. ser. Saintpaul $(n=2)$, $S$. ser. Infantis $(n=6), S$. ser. Panama $(n=3), S$. ser. Madelia $(n=6)$, and $S$. ser. Braenderup $(n=5)$, along with two $S$. enterica subspecies: houtenae $(n=6)$ and enterica $(n=2)$. Most Salmonella strains came from Farm B $(n=24 / 80 \%)$ (Table 1).

Six of the Salmonella strains were resistant to one or more of the following antibiotics: AMP, OTC, TET, and NIT. Among the isolates, three multidrug-resistent strains (Sw15, Ss16, and Ss17) displayed resistance to three antibiotic classes (penicillin, tetracycline, and nitrofuran). A strain of Salmonella ser. Panama (Sw11) was susceptible to all antibiotics in the antibiogram test. Isolates colonies (subpopulation, strain Sw1la) grew within the inhibition zone of tetracycline disks (TET and OTC) (Table 1).

The results of the plasmid curing revealed that most of the antibiotic-resistant Salmonella expressed resistant phenotype after their incubation with mutagenic agent (acridine orange), indicating that this profile is probably encoded by chromosomal genes. Only one cured strain of Salmonella (Ss17) lost its resistance towards AMP and NIT, indicating that these genes are related to plasmids.

MIC for tetracyclines (TET and OTC) ranged between $32 \mu \mathrm{g}$ and $64 \mu \mathrm{g}$ for strains isolated from river water on Farm A (Sw3) and from inlet canal water (Sw10, Sw11, and Sw15) and sediment on Farm B (Ss16 and Ss17). For tetracyclines, MBC ranged between $64 \mu \mathrm{g}$ and $1024 \mu \mathrm{g}$ (Sw10 and Sw11a*). MIC and MBC for AMP and NIT were above $640 \mu \mathrm{g} / \mathrm{mL}$ (Table 2).

\section{Discussion}

The presence of Salmonella spp. in coastal and inland shrimp culture environments in Northeast Region of Brazil has been recorded by several authors [13-15]. The presence of these bacteria is primarily related to the discharge of untreated 
TABLE 1: Antimicrobial resistance profile of subspecies and serovars of Salmonella enterica isolated from water and sediment samples from ponds and inlet canal (Jaguaribe River) of two freshwater-acclimated Litopenaeus vannamei culture farms (A and B), Ceara, Brazil.

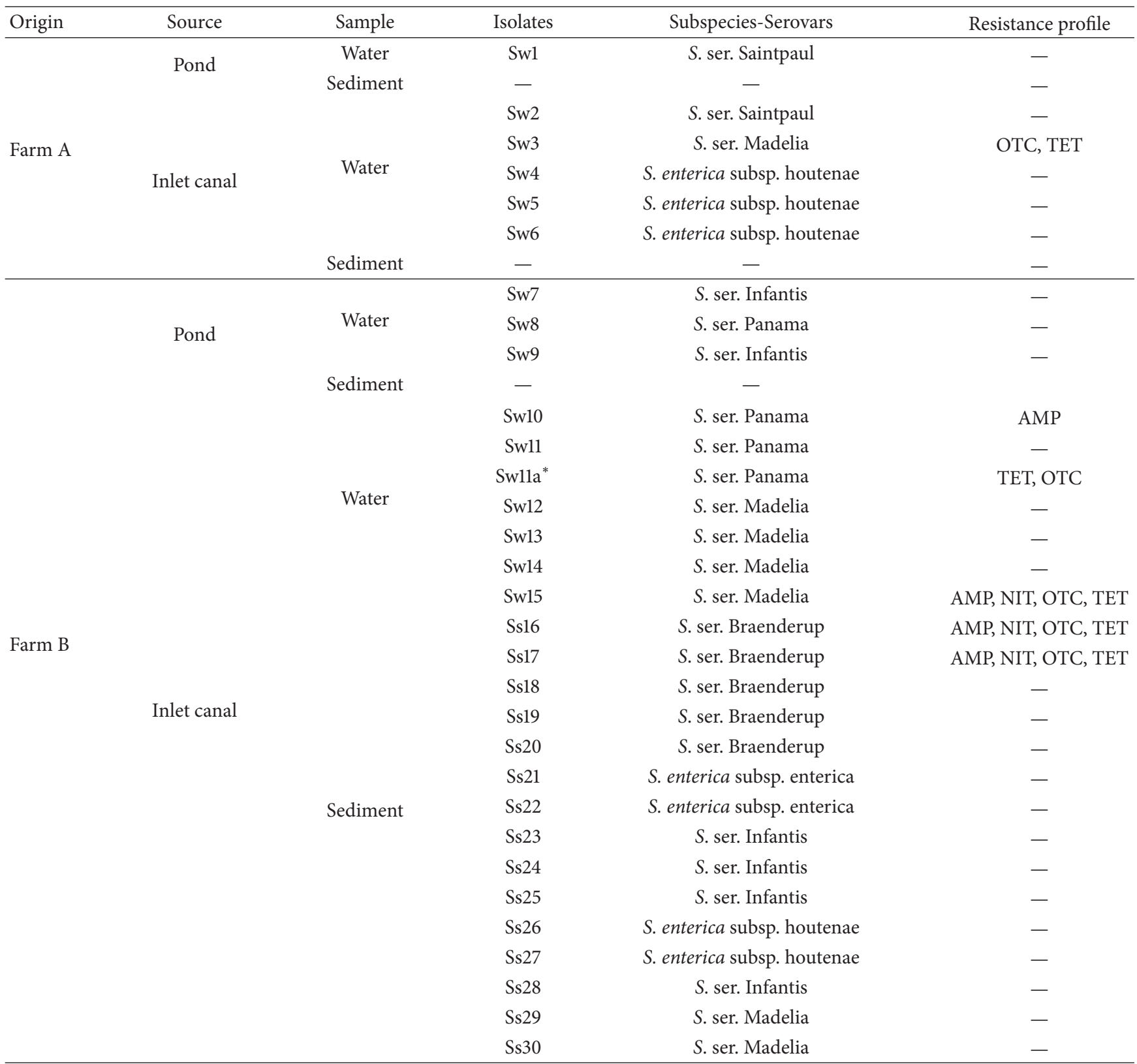

Sw: water-sample Salmonella; Ss: sediment-sample Salmonella; Swlla* : subpopulation.

sewage into local water bodies and also to the reuse of water resources, such as organic fertilizers for irrigation and aquaculture [16].

In a study on shrimp culture environments and livestock in India, Bhaskar et al. [1] found Salmonella in all samples, but concentrations were poorly correlated with bacterial indicators of fecal contamination. This could suggest that Salmonella belong to autochthonous microbiota. According to Reilly et al. [17], pond fertilization with untreated manure is a major source of Salmonella contamination in shrimp farm sediments. This practice, however, is not adopted by Brazilian shrimp farmers; in fact, according to Brito et al. [18], ponds in
Northeast Region of Brazil are fertilized mainly with urea and triple superphosphate, and less frequently with nitrates, phosphates, and sulfates. The presence of Salmonella in Brazilian aquaculture is therefore attributed to the presence of sewage discharge and/or grazing animals in the area surrounding the farm.

Salmonellosis, a major concern in worldwide public health, is characterized by high levels of endemicity and morbidity, and it is particularly difficult to control due to a variety of epidemiological parameters related to multiple sources of infection and routes of transmission throughout the cycle of the disease [19]. In Brazil, fifteen food-related salmonellosis 
TABLE 2: Minimum inhibitory (MIC) and bactericidal (MBC) concentrations of antibiotics tested against resistant Salmonella spp. strains isolated from water and sediment samples of ponds and inlet canal (Jaguaribe River) in two freshwater-acclimated Litopenaeus vannamei culture farms (A and B), Ceara, Brazil.

\begin{tabular}{|c|c|c|c|c|c|c|c|c|c|c|}
\hline \multirow{4}{*}{ Location } & \multirow{4}{*}{ Sample } & \multirow{4}{*}{ Isolates } & \multicolumn{8}{|c|}{ Concentration $(\mu \mathrm{g})$} \\
\hline & & & \multicolumn{4}{|c|}{ Tetracycline } & \multirow{2}{*}{\multicolumn{2}{|c|}{$\begin{array}{c}\text { Penicillin } \\
\text { AMP }\end{array}$}} & \multirow{2}{*}{\multicolumn{2}{|c|}{$\begin{array}{l}\text { Nitrofuran } \\
\text { NIT }\end{array}$}} \\
\hline & & & \multicolumn{2}{|c|}{ TET } & \multicolumn{2}{|c|}{ OTC } & & & & \\
\hline & & & MIC & $\mathrm{MBC}$ & MIC & $\mathrm{MBC}$ & MIC & $\mathrm{MBC}$ & MIC & $\mathrm{MBC}$ \\
\hline Farm A & Inlet canal & Sw3 & 64 & 256 & 64 & 128 & - & - & - & - \\
\hline \multirow{5}{*}{ Farm B } & \multirow{5}{*}{ Inlet canal } & Sw10 & 64 & 64 & 64 & 64 & 640 & $>640$ & - & - \\
\hline & & Sw1la* & 64 & 256 & 128 & 1024 & - & - & - & - \\
\hline & & Sw15 & 128 & 256 & 64 & 512 & $>640$ & $>640$ & 6400 & $>12800$ \\
\hline & & Ss16 & 64 & 256 & 64 & 512 & $>640$ & $>640$ & 6400 & $>12800$ \\
\hline & & Ss17 & 64 & 256 & 64 & 512 & $>640$ & $>640$ & 12800 & $>12800$ \\
\hline
\end{tabular}

Sw: water-sample Salmonella; Ss: sediment-sample Salmonella; - : test not performed for this antibiotic.

* Subpopulation.

outbreaks were officially registered between 2000 and 2008 related with a wide variety of food sources [20].

The results of this study have disclosed two public health problems: (1) the presence of resistant Salmonella strains in Northeast Brazilian shrimp culture and (2) the possibility of Salmonella infection in humans through the consumption of contaminated shrimp, along with economic losses as a result of reduced exports to international markets with high standards of control of pathogens in productive and processing systems.

The isolation of antibiotic-resistant strains might suggest the use of drugs in that aquatic environment. Continuous and improper use of this antibiotic may increase the incidence and resilience of resistant strains, thereby compromising human food safety and creating a difficulty in treating human salmonellosis. In many countries, the irresponsible use of antibiotics in animal husbandry is considered a major cause of increased bacterial resistance [21-23]. In fact, Cabello [24] discussed the effect of selective pressure of antibiotic drug residue on the microbial composition in aquaculture pond sediments.

The binding of antibiotic to sediment particles delays its biodegradation and explains long-term permanence of the drugs in the environment. Drugs of the NIT group have been banned since 2003 from veterinary practice and food production (Ministry of Agriculture, Norm no. 09) [25], and NITresistant bacteria are still isolated in shrimp farm sediments. It was possible to verify resistance to high concentrations of antibiotics (NIT and AMP) among the Salmonella spp. isolated in Farm B from both water and sediment samples (Table 2).

It should be noted that OTC-resistant Salmonella strains were also observed in this study. In fact, this antibiotic is widely used by shrimp farmers in the region to the treatment of bacterial disease in shrimp culture [26]. Due to low absorption, the recommended dose is $5-10$ times greater than the average dose used in medical care. Thus, most OTC administered in aquaculture inevitably accumulates in pond sediments [27]. Tetracyclines and oxytetracyclines have binding sites for metal ions, especially magnesium and calcium [28].
When tetracyclines are administered in salt water, ionbinding can reduce biological activity [29]. The shrimp farms sampled for this study were located in a freshwater environment, but the inlet water (from the Jaguaribe River) was moderately hard, indicating a relative abundance of calcium and magnesium ions [30]. In other words, the hardness of the freshwater used on the shrimp farms in the study could be interfering with the action of tetracyclines.

To conclude, the results in the present study revealed the presence of Salmonella strains resistant to antimicrobials in cultured freshwater-acclimated L. vannamei farms. The incidence of bacteria pathogenic to humans in a shrimp farming environment, as well as their drug-resistance pattern revealed in this study, emphasizes the need for a more rigorous attention to this area.

\section{Conflict of Interests}

The authors declare that there is no conflict of interests regarding the publication of this paper.

\section{Acknowledgments}

The authors would like to thank the Ministry of Health (SUS) for financial support. The authors also received support from FUNCAP, CNPq, and LABOMAR/UFC.

\section{References}

[1] N. Bhaskar, T. M. Setty, G. V. Reddy et al., "Incidence of Salmonella in cultured shrimp Penaeus monodon," Aquaculture, vol. 138, no. 1-4, pp. 257-266, 1995.

[2] M. Boaventura, A. Canuto, and A. Ferreira, "Novas diretrizes no cultivo de camarão cinza Litopenaeus vannamei para o controle das enfermidades," Revista Aquicultura \& Pesca, vol. 17, pp. 2528, 2006.

[3] S. Harakeh, H. Yassine, and M. El-Fadel, "Antimicrobialresistant patterns of Escherichia coli and Salmonella strains in the aquatic Lebanese environments," Environmental Pollution, vol. 143, no. 2, pp. 269-277, 2006. 
[4] A. M. S. Cardonha, R. H. S. F. Vieira, H. N. Holland, J. L. S. Melo, M. A. S. Bezerra, and K. S. F. S. C. Damasceno, "Monitoramento da Poluição da água das galerias pluviais e do mar por meio de avaliação físico-química e microbiológicas," Arquivo de Ciencias do Mar, vol. 38, pp. 43-48, 2005.

[5] P. S. A. Pinto, "Aspectos sanitários da Salmonelose como uma zoonose," Higiene Alimentar, vol. 14, pp. 39-43, 2000.

[6] CDC, Salmonella Surveillance, Centers for Disease Control and Prevention, Atlanta, Ga, USA, 1996.

[7] CDC, "National Antimicrobial Monitoring System," Annual Report, Centers for Disease Control and Prevention, Atlanta, Ga, USA, 1996.

[8] H. A. Wallace and T. S. Hammack, "Salmonella," in U.S. Food and Drugs Administration, Center for Food Safety \& Applied Nutrition. Bacteriological Analytical Manual, FDA/CFSAN, 2005, http://www.fda.gov/Food/FoodScienceResearch/LaboratoryMethods/ucm070149.htm.

[9] L. Le Minor and M. Y. Popoff, "Designation of Salmonella enteric sp. nov. nom.rev.as the type and only species of the genus Salmonella," International Journal of Systematic Bacteriology, vol. 37, pp. 465-468, 1987.

[10] A. W. Bauer, W. M. Kirby, J. C. Sherris, and M. Turck, "Antibiotic susceptibility testing by a standardized single disk method," American Journal of Clinical Pathology, vol. 45, no. 4, pp. 493496, 1966.

[11] CLSI-Clinical and Laboratory Standards Institute, "Performance standards for antimicrobial susceptibility testing: nineteenth informational supplement M100-S19," Tech. Rep. 26, 2010.

[12] A. Molina-Aja, A. García-Gasca, A. Abreu-Grobois, C. BolánMejía, A. Roque, and B. Gomez-Gil, "Plasmid profiling and antibiotic resistance of Vibrio strains isolated from cultured penaeid shrimp," FEMS Microbiology Letters, vol. 213, no. 1, pp. 7-12, 2002.

[13] L. S. Parente, R. A. Costa, G. H. F. Vieira et al., "Bactérias entéricas presentes em amostras de água e camarão marinho Litopenaeus vannamei oriundos de fazendas de cultivo no Estado do Ceará, Brasil," Brazilian Journal of Veterinary Research and Animal Science, vol. 48, pp. 46-53, 2011.

[14] F. C. T. Carvalho, N. S. Evangelista-Barreto, C. M. F. Reis, E. Hofer, and R. H. S. F. Vieira, "Susceptibilidade antimicrobiana de Salmonella spp. isoladas de fazendas de carciniculturas no Estado do Ceará," Revista Ciencias Agronomica, vol. 40, pp. 549556, 2009.

[15] M. C. B. Figueiredo, L. F. P. Araújo, R. B. Gomes, and M. F. Rosa, "Impactos ambientais do lançamento de efluentes da carcinicultura em águas interiores," Engenharia Sanitária e Ambiental, vol. 10, pp. 167-174, 2005.

[16] R. V. Ribeiro, E. M. F. Reis, C. M. F. Reis, A. C. Freitas Almeida, and D. P. Rodrigues, "Incidence and antimicrobial resistance of enteropathogens isolated from an integrated aquaculture system," Letters in Applied Microbiology, vol. 51, no. 6, pp. 611-618, 2010.

[17] P. J. A. Reilly, D. R. Twiddy, and R. S. Fuchs, "Review on the occurrence of Salmonella in cultured tropical shrimp," FAO Fisheries Circular, vol. 851, p. 19, 1992.

[18] L. O. Brito, W. M. Costa, and A. Oliveira, "Importância da Fertilização em Viveiros de Camarão Marinho," Revista Panorama da Aquicultura, vol. 8, pp. 35-37, 2006.

[19] E. Hofer and S. J. Silva, "Sorovares de Salmonella isolados de matérias-primas e de ração para aves no Brasil," Pesquisa Veterinária Brasileira, vol. 18, pp. 21-27, 1998.
[20] Brazil-Ministério da Saúde, "Secretaria de Vigilância em Saúde," Vigilância Epidemiológica da Febre Tifóide, 2009, http://portal.saude.gov.br/portal/arquivos/pdf/febre_tifoide.pdf.

[21] E. M. Silva and A. Duarte, "Salmonella Enteritidis em aves: retrospectiva no Brasil," Revista Brasileira Ciencias Avicultura, vol. 4, pp. 85-100, 2002.

[22] J. L. Balcázar, I. D. Blas, I. Ruiz-Zarzuela, D. Cunningham, D. Vendrell, and J. L. Múzquiz, "The role of probiotics in aquaculture," Veterinary Microbiology, vol. 114, no. 3-4, pp. 173-186, 2006.

[23] R. Helena Rebouças, O. Viana de Sousa, A. Sousa Lima, F. Roger Vasconcelos, P. B. de Carvalho, and R. H. S. dos Fernandes Vieira, "Antimicrobial resistance profile of Vibrio species isolated from marine shrimp farming environments (Litopenaeus vannamei) at Ceará, Brazil," Environmental Research, vol. 111, no. 1, pp. 21-24, 2011.

[24] F. C. Cabello, "Heavy use of prophylactic antibiotics in aquaculture: a growing problem for human and animal health and for the environment," Environmental Microbiology, vol. 8, no. 7, pp. 1137-1144, 2006.

[25] Brazil-Ministério da Agricultura e do Abastecimento, "Secretaria de Defesa Agropecuária," Instrução Normativa No9, DE 27 de junho de 2003. Publicado no Diário Oficial da União de 30/06/2003, Seção 1, Página 4.

[26] A. C. Nogueira-Lima, T. C. V. Gesteira, and J. Mafezoli, “Oxytetracycline residues in cultivated marine shrimp (Litopenaeus vannamei Boone, 1931) (Crustacea, Decapoda) submitted to antibiotic treatment," Aquaculture, vol. 254, no. 1-4, pp. 748757, 2006.

[27] B. T. Lunestadt and J. Goksoyr, "Reduction in the antibacterial effect of oxytetracycline in sea water by complex formation with magnesium and calcium," Diseases of Aquatic Organisms, vol. 9, pp. 67-72, 1990.

[28] L. Lambs, M. Brion, and G. Berthon, "Metal ion-tetracycline interactions in biological fluids. III. Formation of mixed-metal ternary complexes of tetracycline, oxytetracycline, doxycycline and minocycline with calcium and magnesium, and their involvement in the bioavailability of these antibiotics in blood plasma," Agents and Actions, vol. 14, no. 5-6, pp. 743-750, 1984.

[29] FAO, "Responsible use of antibiotics in aquaculture," Paper 469, Food and Agriculture Organization of the United Nations, 2005.

[30] F. R. Miranda, R. N. Lima, L. A. Crisóstomo, and M. G. S. Santana, "Reuse of inland low-sal inity shrimp far m effluent for melon irrigation," Aquacultural Engineering, vol. 39, pp. 1-5, 2008. 


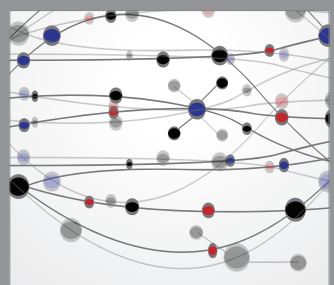

The Scientific World Journal
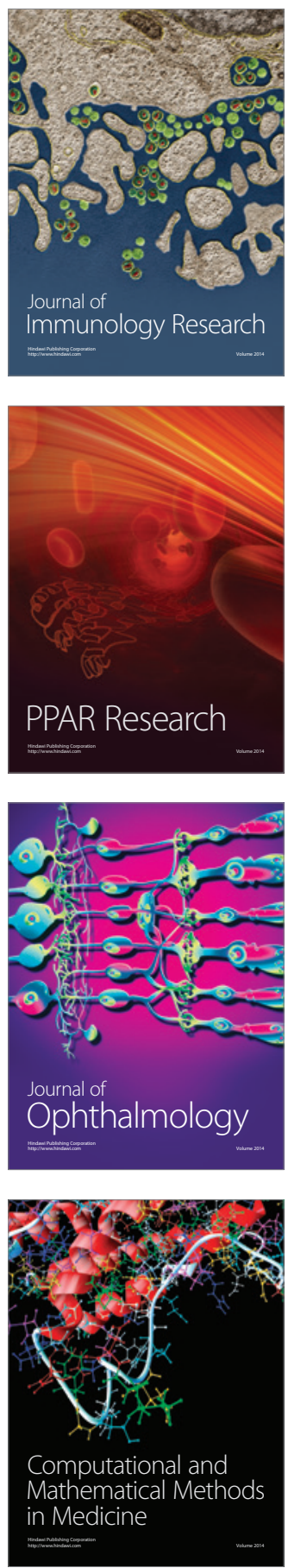

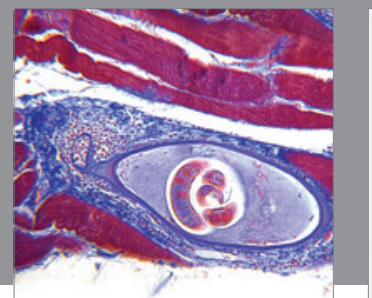

Gastroenterology

Research and Practice
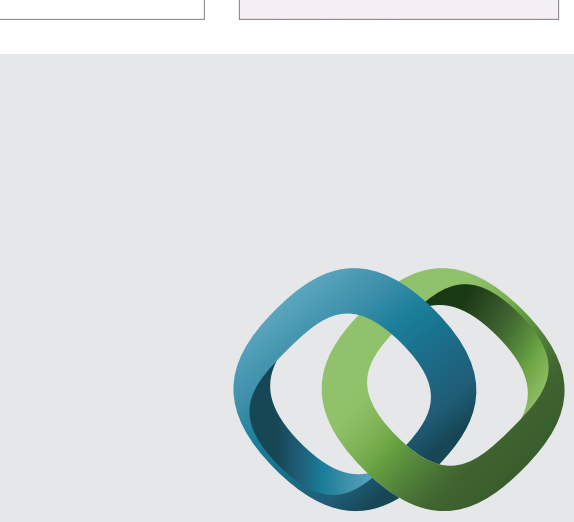

\section{Hindawi}

Submit your manuscripts at

http://www.hindawi.com
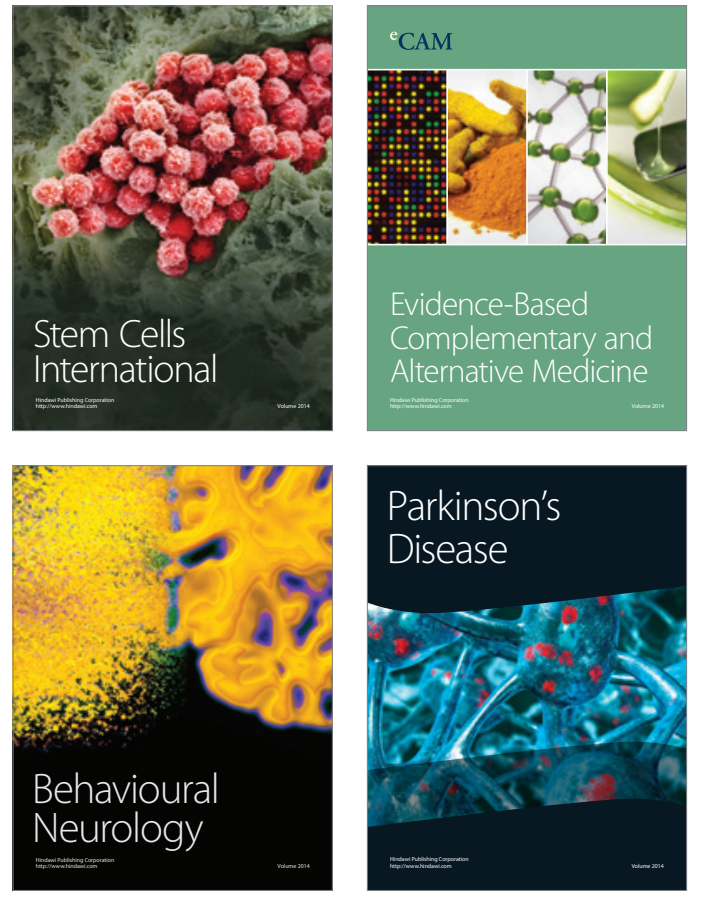
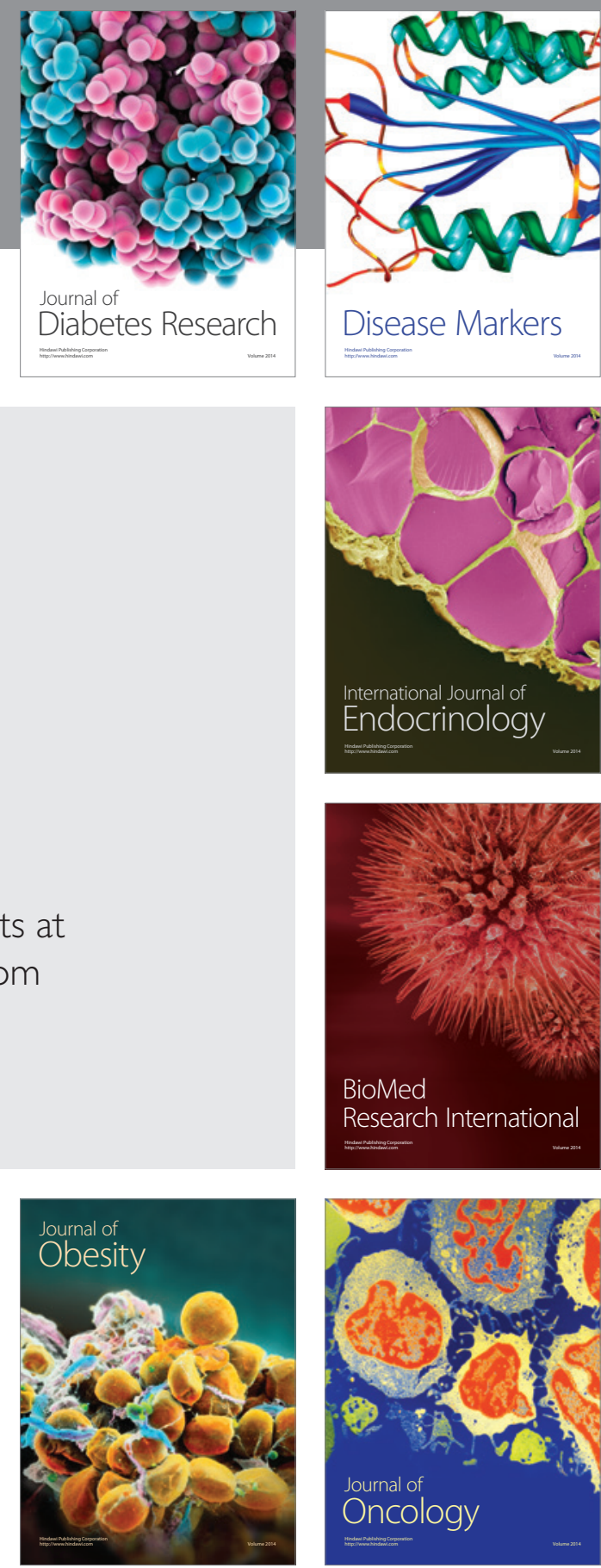

Disease Markers
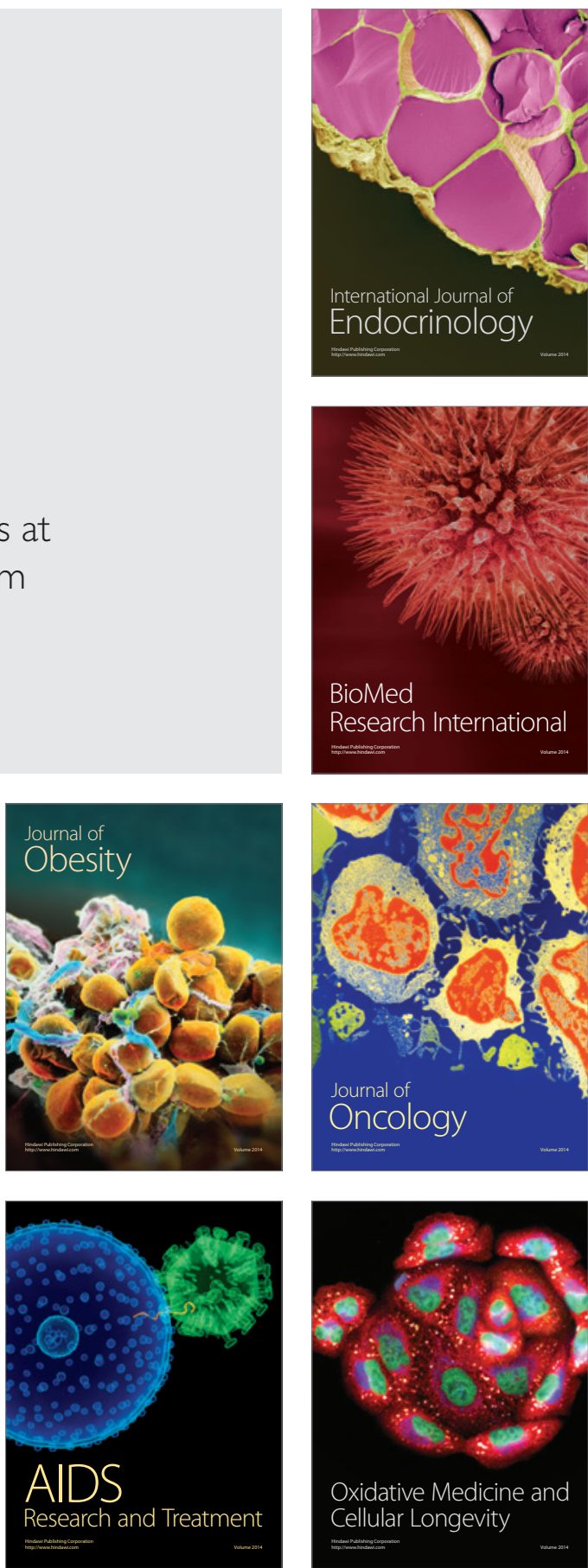